\title{
Transverse grooved artefacts from southwestern Asia and northern Eurasia: Common traits and the reconstruction of function
}

\author{
Irina Usacheva
}

Institute of the Problems of Northern Development, Siberian Branch, Russian Academy of Sciences. Malygina

86, Tyumen, 625003, Russia. Email: i.usachova@gmail.com

\begin{abstract}
:
Transverse grooved artefacts (TGA) appeared as a new cultural element in Mesolithic-ProtoNeolithic sites in southwestern Asia. We know of similar artefacts from northern Africa. Hundreds of TGA have also been found in northern Eurasia. Some common traits were found in specimens from far apart territories, such as the non-abrasive heat-resistant nature of the raw materials, specificity of fragmentation without any signs of physical impact, the standard size of the grooves, association with a specific type of landscape, the similar economic level of the societies with which the items are associated, and use-wear marks in the grooves. Based on these regularities we can speak of a single main function for these artefacts which support the earlier reconstruction of R.L. and R.S. Solecki, suggesting that grooved stones were used for straightening cane and reed shafts under heating. Other evidence and traces that have been identified on the surface of TGA outside the groove could be associated with a variety of additional functions.
\end{abstract}

Keywords: transverse grooved artefacts; grooved stones; shaft straighteners; utyuzhki MesolithicProto-Neolithic; southwestern Asia; ground stone tools

\section{Introduction}

In 1970 Solecki \& Solecki (1970) drew our attention to a category of Near Eastern grooved stones. This was the most complete and comprehensive study of grooved artefacts at the time. Today, the term "grooved stones" covers a wider variety of artefacts than was initially suggested by the authors. This includes different types of grooved stone tools with distinguishable functions. Currently, grooved stone artefacts are distinguished as used for the production, maintenance, and sharpening of bone awls, needles and other pointed objects, and transverse-grooved stones crafted out of mostly non-abrasive rocks (these items are also referred to as "arrow shaft straighteners," "pierres à rainures," "shaft-straighteners," "polissoirs," and "polissoirs à rainures". Wilke \& Quintero (2009: 127-128) described such lithic category confusion in much detail. On the other hand, it does not cover ceramic artefacts with grooves identical to those observed in stone artefacts (Usacheva 2007: 44-45;

Published by the School of History, Classics and Archaeology, University of Edinburgh ISSN: 2055-0472. URL: http://journals.ed.ac.uk/lithicstudies/

This work is licensed under a Creative Commons Attribution 2.5 UK: Scotland License. 
Wilke \& Quintero 2009: 128-129). To correct this situation, the term "transverse grooved artefacts” (TGA) is offered for items with a groove running across the short axis. TGA make up a category of grooved samples which include small $(3-23 \mathrm{~cm}$, most often $6-12 \mathrm{~cm}$ in length) stone or ceramic specimens varying in shape, quality, and decoration, with transverse grooves of small diameter.

Our present investigation is devoted to such transverse grooved artefacts (Figure 1), which were also the focus of Solecki \& Solecki (1970).

Solecki and Solecki (1970) stated that TGA appeared as a new cultural element in Epipaleolithic-Proto-Neolithic sites in a broad geographic zone from southwestern Asia to northern Africa. Similar objects have been recorded from archaeological and ethnographic contexts in both the Old World and the New World (Solecki \& Solecki 1970: 831). Solecki and Solecki's (1970) investigation included detailed descriptions of the Near Eastern grooved stones as well as a comparative analysis of these artefacts with archaeologically and ethnographically identical objects from southwestern Asia, Africa and North America. Specifically useful parallels for archaeological interpretation of the function and use of Near Eastern grooved stones were found among the American Indians and the Bushmen of southern Africa, where such stones were used as reed shaft straighteners under heat application. The researchers concluded that the nature of TGA was multifunctional, with their primary function being to straighten reed and cane shafts under heating (Solecki \& Solecki 1970: 838). Other hypotheses of the functional purpose of grooved stones, with both utilitarian and sacral modalities, also exist, although they are not as well-founded (Solecki \& Solecki 1970: 838; Usacheva 2012).

Archaeological investigations of the Natufian sites in the southern Levant provide evidence that grooved stones (including full morphological prototypes of TGA) originated during the Early Natufian (Weinstein-Evron et al. 2012; Rosenberg et al. 2014: 97). Such early dates support the hypothesis that the manufacturing tradition of the grooved stones originated in the Near East. This is also supported by the variable position of the grooves (both longitudinal and transverse grooves are widely distributed), the internal morphology of the groove (which may have a rounded profile but also triangular or rectangular modifications) and the specific raw material (mainly compact basalt - a non-typical material for common TGA which are usually made from softer non-abrasive rocks, such as steatite, chlorite etc.). Dozens of grooved stones have now been identified across the Near East (Kozlowski \& Aurenche 2005: 158-160).

In the archaeological collections of northern Eurasia we find similar small artefacts made of stone or clay, with transverse, or less commonly, longitudinal, grooves (Figures 2 and 3).

They are found over a vast territory which includes Eastern Europe (the European part of Russia, Ukraine, Moldavia), Transcaucasia, Central (Kazakhstan, Tajikistan, Uzbekistan, Mongolia) and northern Asia (Western Siberia), and the Urals and Altay Mountains (Figure 4). Such objects, called "arrow shaft straighteners," "polishers," "grindstones," "utyuzhki," (Russian) "praski," and "chovniki” (Ukrainian), number by the hundreds, although they are only occasional finds. TGA are especially numerous throughout the Ukraine (the Dnieper River) and the Urals as well as the Near East (Levant and Zagros). These artefacts are associated with different cultural contexts (at least sixty cultures) ranging from the Mesolithic to the Early Bronze Age $\left(9^{\text {th }}\right.$ - early $2^{\text {nd }}$ millennia BCE). In the most recent period of their existence, the number of TGA is reduced, and then they disappear completely. TGA in northern Eurasia come from settlements (dwellings or the corresponding archaeological layers), burials and sacred places and sanctuaries. They vary in shape, more than half are decorated (53.8\%), and some are figurines. 

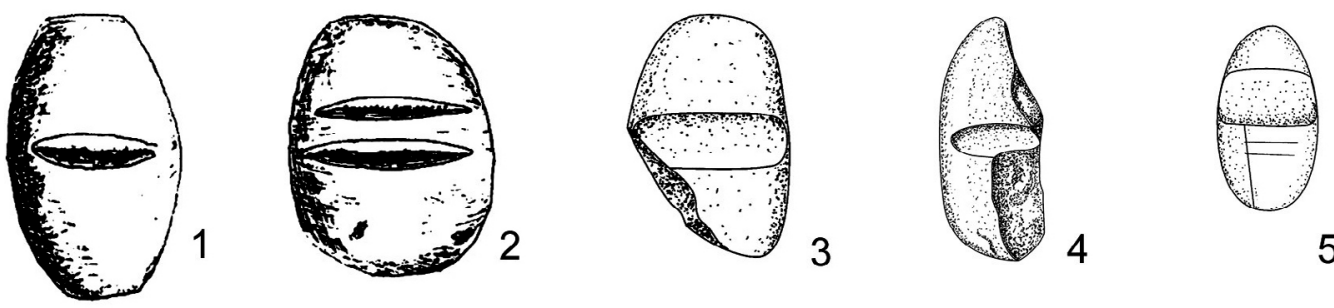

5
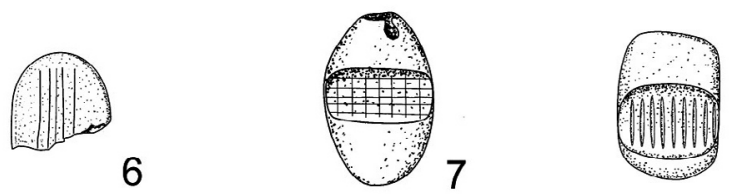

8
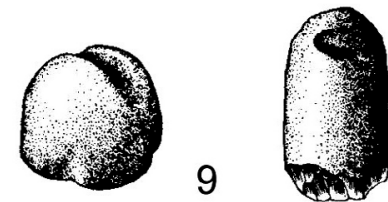

10
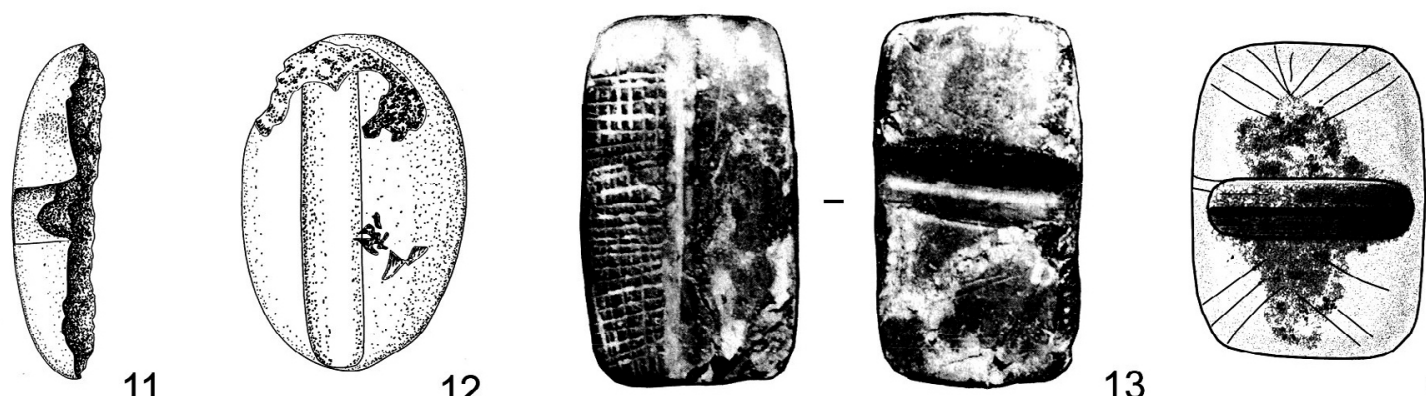

13

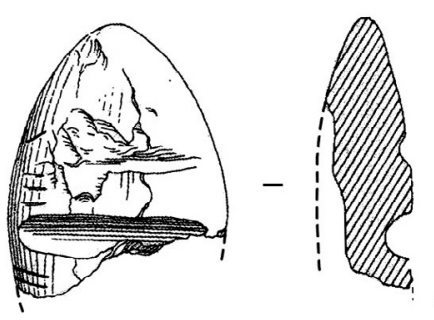

15
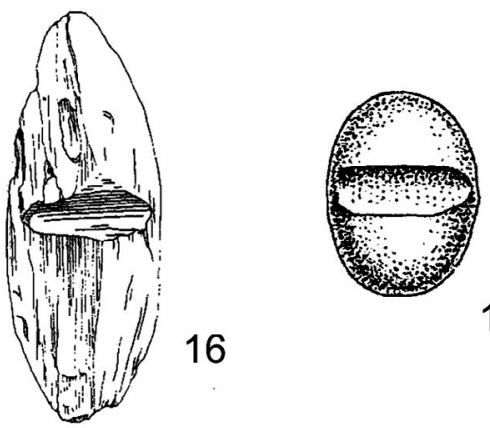

17
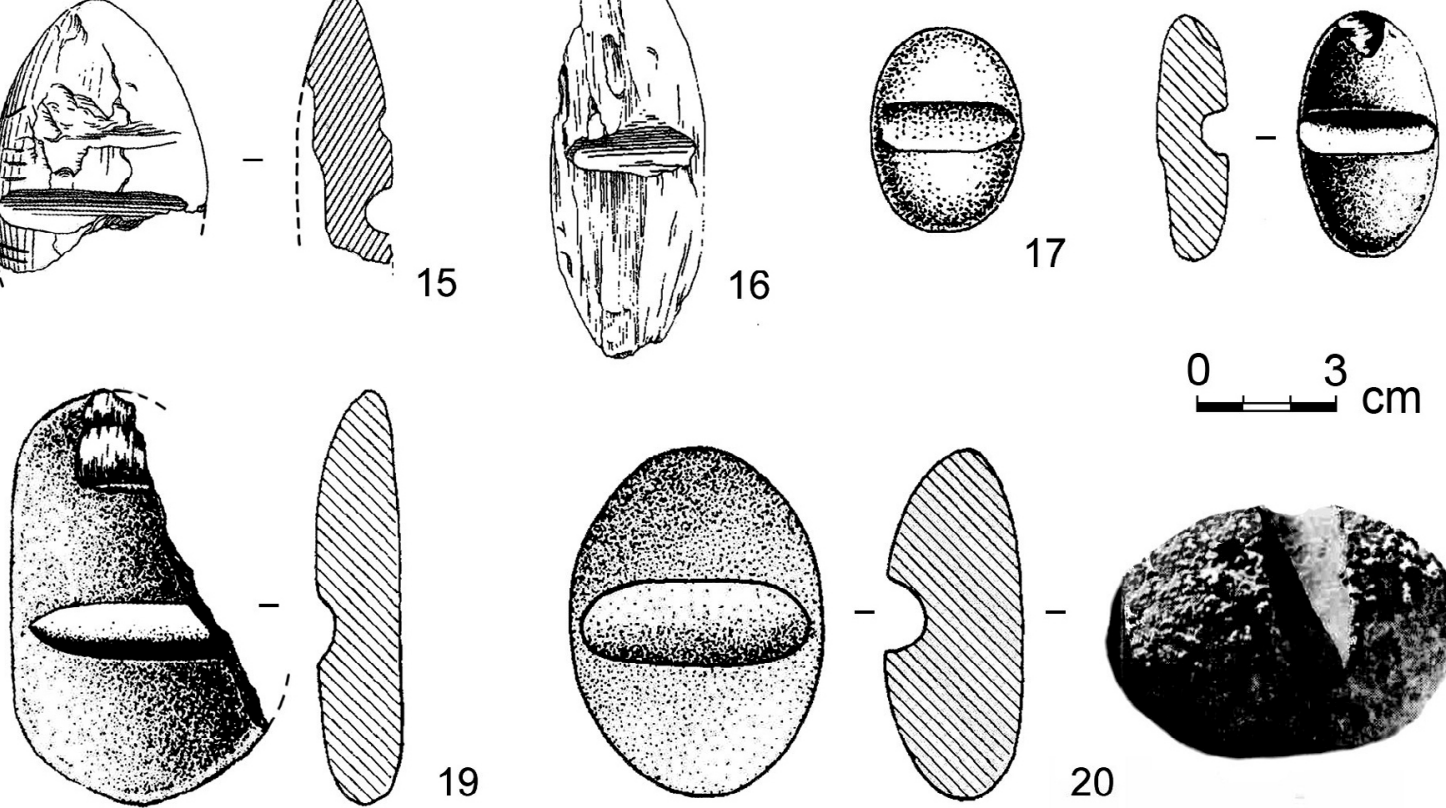

19
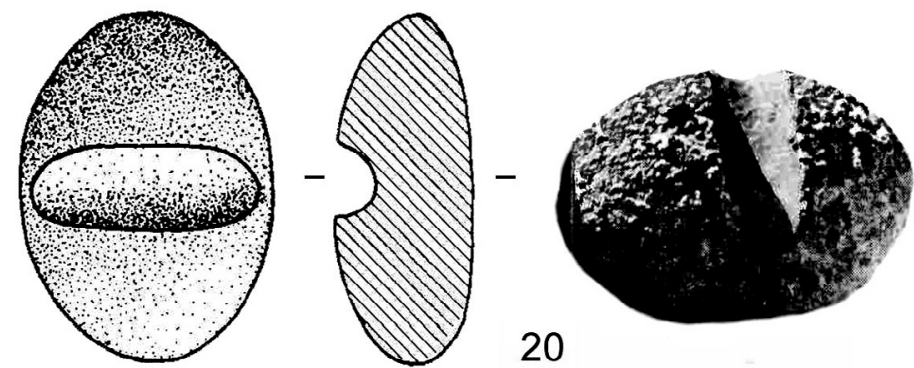

20

Figure 1. Near Eastern grooved stones. 1-8, 11-13, 15-20 - Northern Iraq, 9-10 - Jordan, 14 - Turkey (1, 5, 6 Shanidar Cave; 2-4, 7-8, 11-12 - Zawi Chemi Shanidar (Solecki \& Solecki 1970: fig. 1); 9-10 - El-Chiam (Müller-Karpe 1968: taf. 102, C-1, 2); 13 - Kultepe (Bader 1982: fig. 4); 14 - Demirci Hoyuk (Algaze et al. 1991: fig. 4, 2); 15-17 - Karim Shahir (Mellaart 1982: fig. 2; Braidwood et al. 1983: fig. 12, 1-2); $18-20$ - Jarmo (Braidwood et al. 1983: fig. 131, 12-14). 

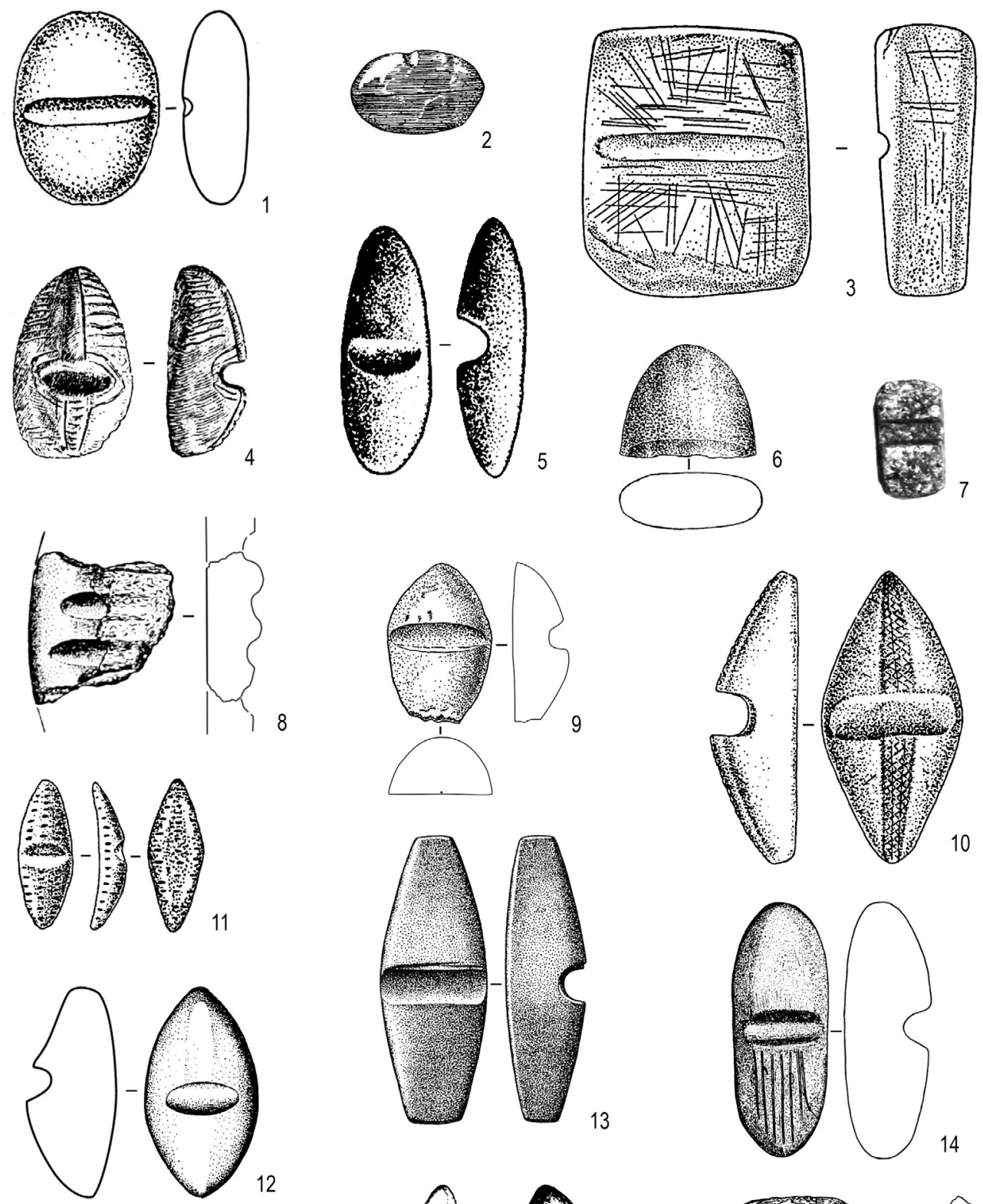

13
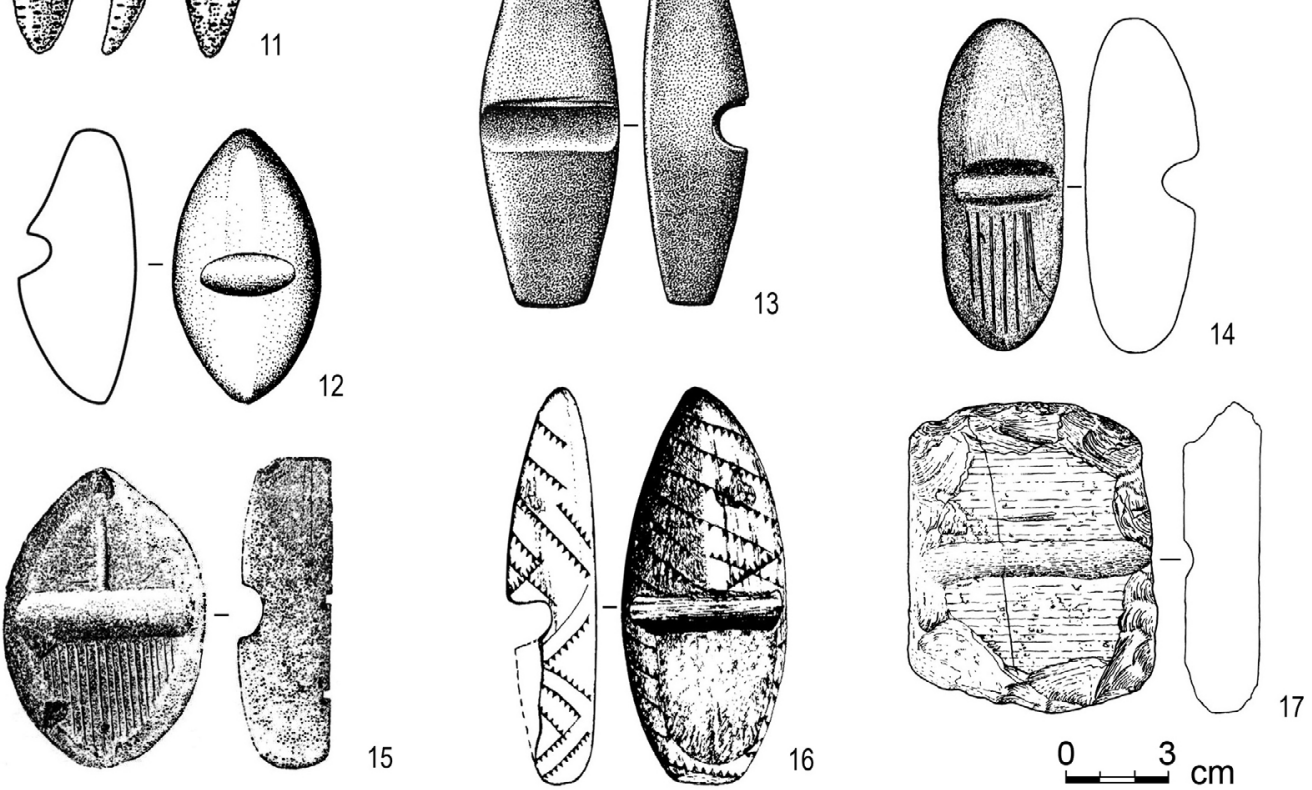

Figure 2. Transverse grooved artefacts from North Eurasia (1-10, 12-17 - stone; 11-ceramic.).1 - Central Asia, Lyavlyakan 340 (Vinogradov \& Mamedov 1975: fig. 42, 2; 2 - Transcaucasia, Anaseuli I (Bzhaniya 1996: fig. 22, 49); 3 - Transcaucasia, Klady (Korobkova \& Sharovskaya 1983: fig. 9, 12); 4 - Ukraine, Vovnigi levoberezhnye (Rudinskij 1956: fig. 10, 3); 5 - Ukraine, Vovnigi pravoberezhnye (Telegin 1968: fig.17, 1); 6 Central Russia, Stanovoe 4 (M.G. Zhilin: personal communication); 7, 9 - Southern Urals, Berezki VIII (Usacheva 2013a: fig. 15, 3, 5); 8 - Southern Russia, Razdorskoe 2 (Cybrij 2004: fig. 2, 7); 10 - Middle Urals, 1e Karas'e ozero (Viktorova \& Kerner 1998: fig. 4, 3) 11 - Middle Urals, Palatki I (Viktorova \& Kerner 1998: fig. 19, 9); 12 - Kazakhstan, Karaganda 15 (Klapchuk 1970: fig. 3, 17); 13 - Siberia, Borovyanka XVII (Hvostov 2001: fig. 1, 2); 14 - Kazakhstan, Bestamak (V.N. Logvin: personal communication); 15 - Siberia, Sopka 2 (Molodin 1992: fig. 41); 16 - Altai, Ust'-Isha (Kiryushin et al. 2000: fig. 25, 22); 17 - Mongolia, Zuuh 7 (Nohrina et al.1996: 1). 

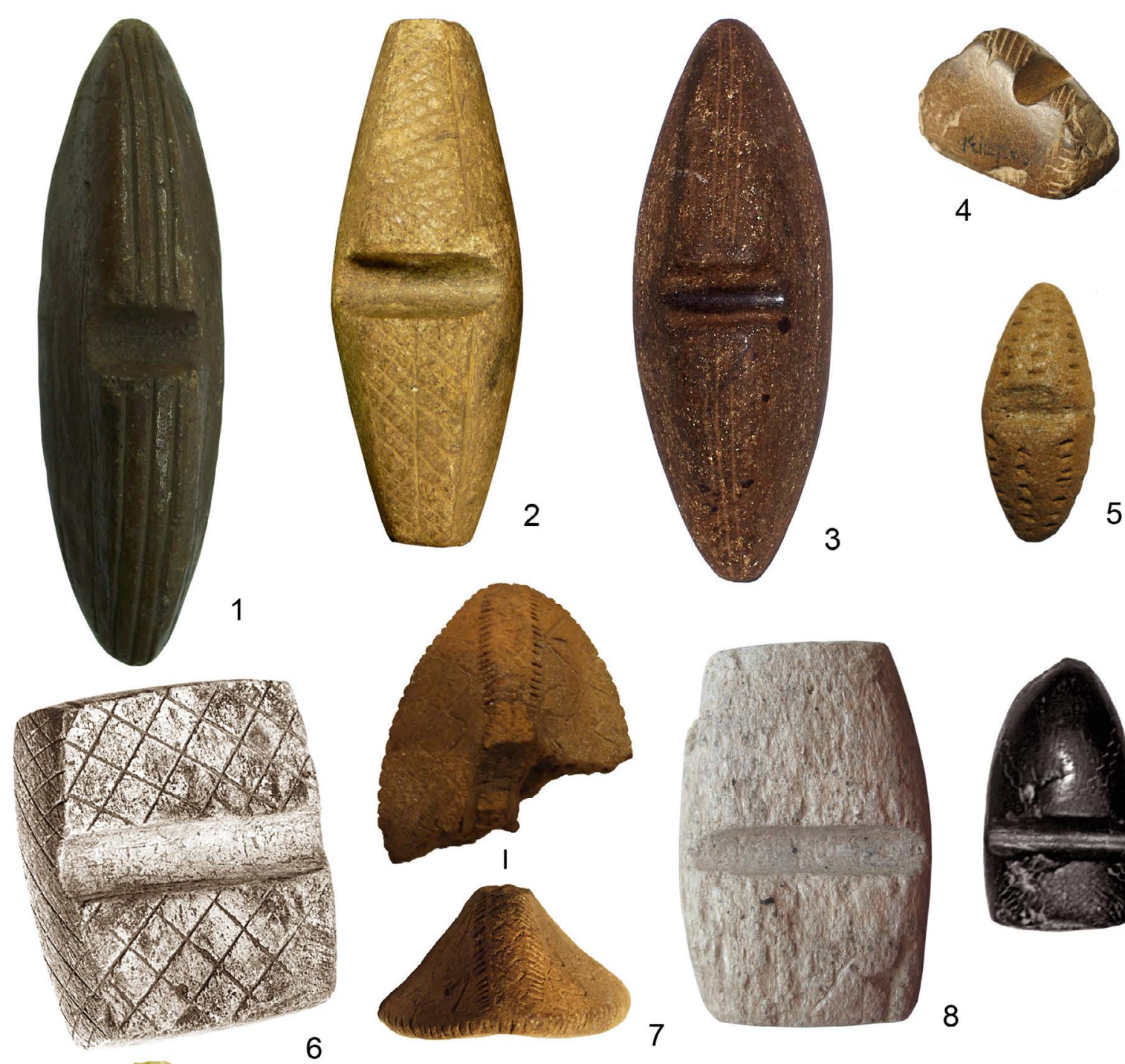

4
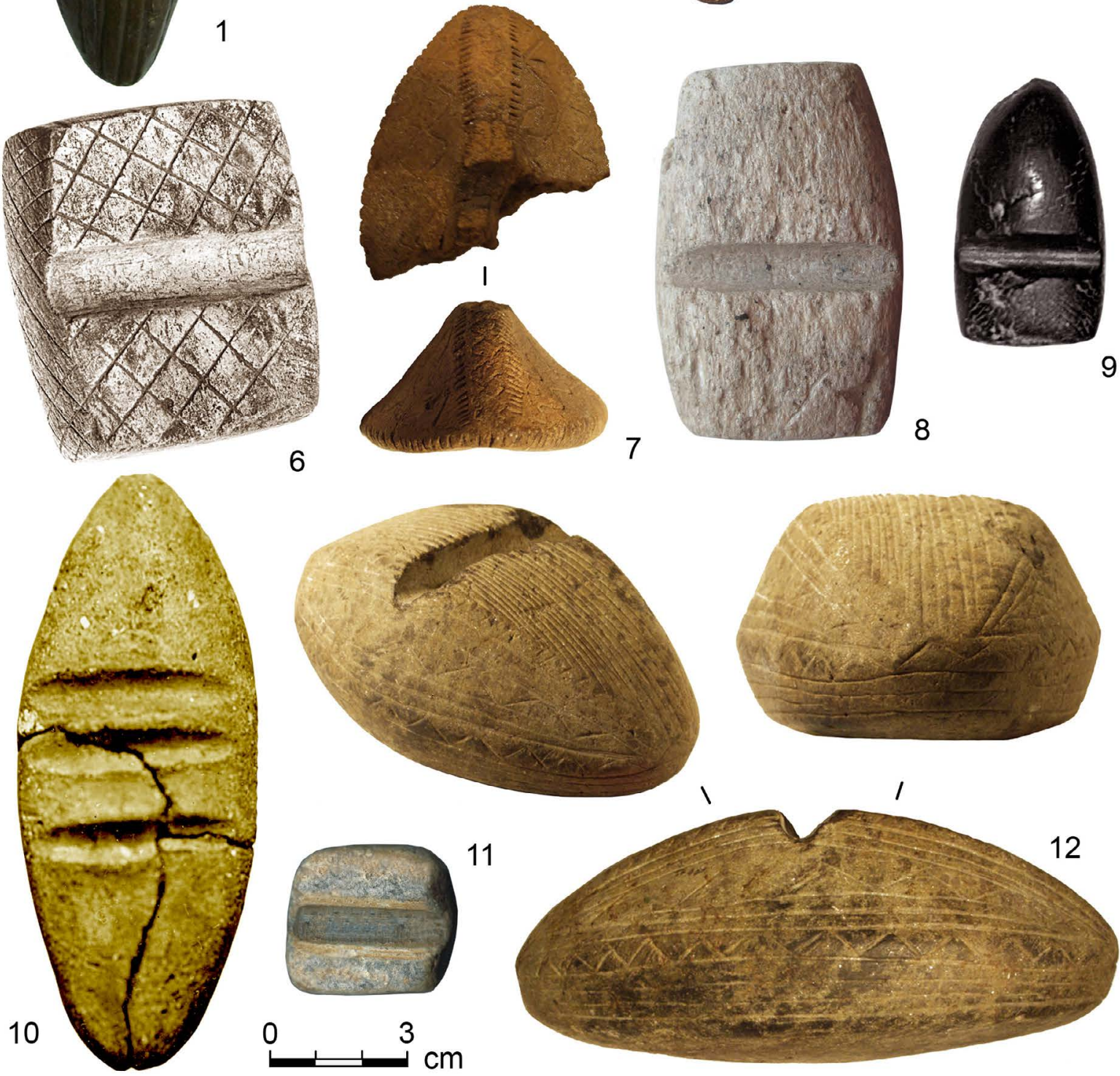

Figure 3. Transverse grooved artefacts from North Eurasia (1, 5, 7, 10 - clay; 2-4, 6, 8-9, 11, 12 - stone). 1, 3, 5, 8, 10 - Middle Urals, Koksharovsky Kholm, Skvortsovskaya Gora-5, Palatki I, Nyazepetrovskaya-2, Koptyaki-9; 2, 7, 12 - Eastern Urals, Kargopolye, Andreyevskaya 1; 4 - Western Siberia, Serebryanka-1; 6 - Southern Urals, Perevozny III; 9 - Altai, Ust’-Isha; 11 - Central Russia, Russko-Shugansky burial ground. 


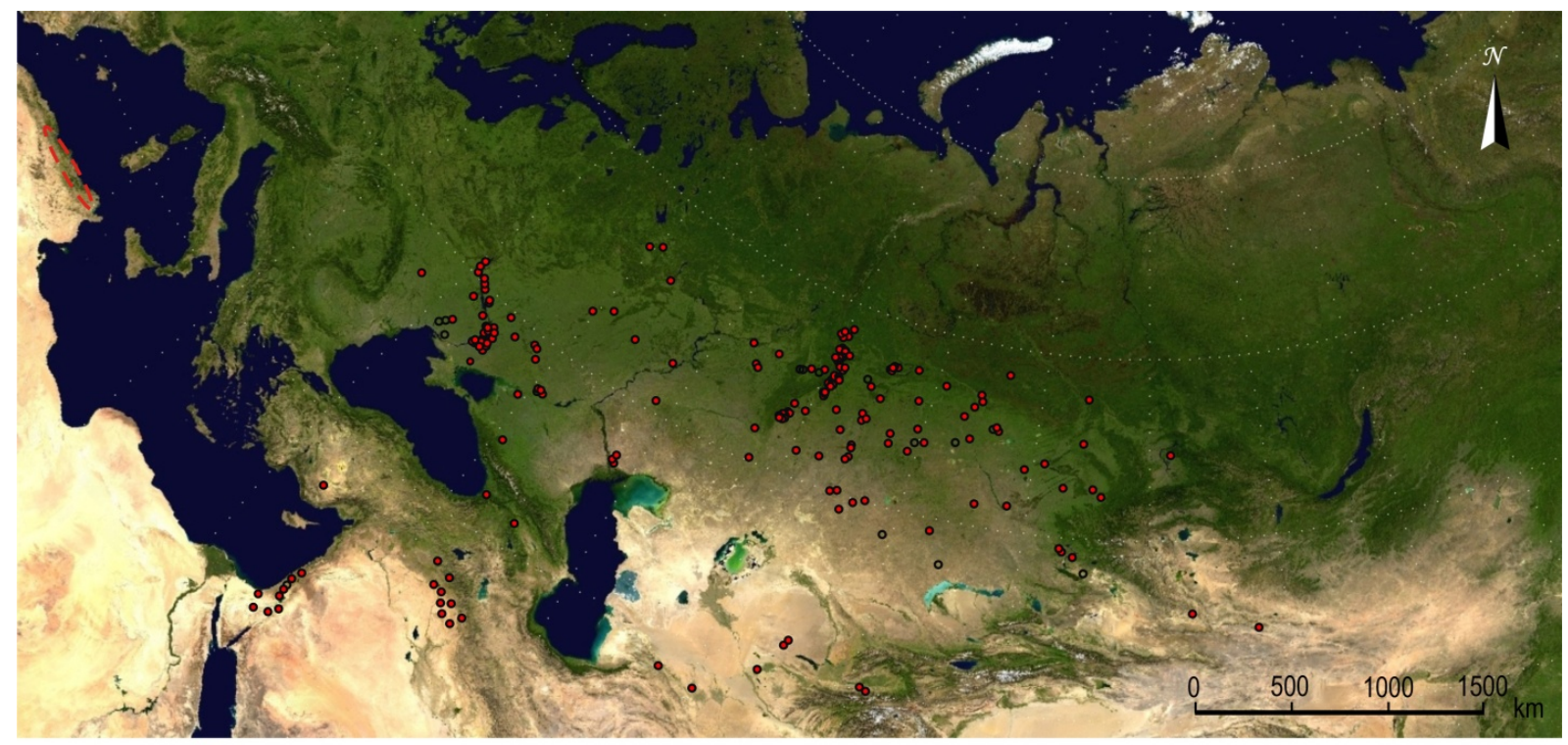

- $a$ a $\quad$ b $\therefore=-; c$

Figure 4. Distribution of transverse grooved artefacts: a. sites with TGA; b. precise location of find unknown; c. distribution of TGA mentioned in the literature without precise data on location. (A composite satellite photograph of Asia in orthographic projection from NASA PD; TGA sites data from Usacheva (2013a: 188189).

Why are TGA so common in northern Eurasia? Are they truly identical to the TGA of southwestern Asia and share common features with them? What can be said about the functional interpretation of TGA? Did they serve a special function, consistent across the whole territory of their occurrence? To what degree can we identify this function with the production and, consequently, the spread of reed arrows?

In 2007 the analysis of a large number of samples (450 items) of TGA included the 78 Near Eastern specimens available for study (Usacheva 2007, 2013a). We examined the size and morphology of the artefacts and the grooves, the material, weight, degree of preservation, visual traces within and outside the grooves, trace evidence in the grooves, as well as on the whole artefacts (more than 70 items), variations and morphology of décor, their placement within the site, the site location, their environmental and cultural contexts, distribution, and chronology, totalling about 50 attributes.

\section{Facts relating to TGA}

The analysis resulted in the following conclusions: the TGA of northern Eurasia and the Near East have some common features. These include the similarity of the petrographic features of raw material (mostly soft, non-abrasive, heat-resistant rocks), massive fragmentation of TGA and characteristics of fractures (without any sign of physical impact which supports the idea that fire was the cause of fracturing), the uniform shape and size of the grooves, the similar environmental contexts of the sites (the predominance of steppe, forest-steppe and other landscapes), identical use-wear traces in the grooves, and, finally, the comparable economic features of the cultures that used TGA.

\subsection{Raw materials}

Approximately $80 \%$ of TGA (Table 1) are crafted out of extremely soft (hardness on the Mohs scale does not exceed 6, but most often 2-3) non-abrasive rocks, which, in the samples studied, were identified as talc, soapstone or steatite (talc-chlorite), chlorite or talc-carbonate 
schists, etc. (Usacheva 2013a: 66-68, table 7). The actual percentage may be much higher, but some of the specimens were not yet identified, and some have been only tentatively identified.

Table 1 Raw materials of transverse grooved artefacts

\begin{tabular}{lcc}
\hline Material & Total & $\%$ \\
\hline Talc schist & 164 & 51.4 \\
Chlorite schist & 79 & 24.8 \\
Schist & 15 & 4.7 \\
Ceramics & 32 & 10.0 \\
Argillite & 2 & 0.6 \\
Hornstone & 1 & 0.3 \\
Amphibolite & 2 & 0.6 \\
Shale & 3 & 0.9 \\
Granite (?) & 1 & 0.3 \\
Pumice & 1 & 0.3 \\
Tuffet & 1 & 0.3 \\
Limestone & 3 & 0.9 \\
Serpentinite & 2 & 0.6 \\
Petrified wood & 1 & 0.3 \\
Basalt & 2 & 0.6 \\
Diorite & 1 & 0.3 \\
Sandstone & 8 & 2.5 \\
Fine-grained quartzite & 1 & 0.3 \\
Total & 319 & 100 \\
\hline
\end{tabular}

Apart from being soft, these rocks have other shared properties, such as being heatresistant and having high calorific capacity (Shekov et al. 2010: 171-172; Gornaya entsiklopediya 2015). Many facts suggest that these properties were well known to the populations contemporary with TGAs and were intentionally selected (see for example, Semenov 1968: 30). Some TGA appear to have been manufactured from water-rolled pebble blanks, as indicated by their rounded profile and the remains of naturally weathered surfaces, but in most cases the original surface of the pebble was completely removed by specific shaping. In areas lacking soft stone, TGA were sometimes worked out of harder stone, such as amphibolites or basalt, or they were made of ceramic (10\%). The latter are represented by baked clay artefacts formed with the help of a special mould (30 items) (Figure 3: 1, 5, 7, 10, 12 ) as well as some fragments of pottery with a groove (3 items).

Fired clay has the same fire-resistant property as the heat-resistant rocks described above. The appearance of ceramic TGA, as well as harder stone items, are associated with the artefact assemblages of migrants, who most often brought stroke-ornamented pottery (Bader \& Kalinina 2003; Yudin 2004; Bobrov et al. 2006; Vybornov 2008; Usacheva 2013a) with them. They had lost access to their old deposit fields and did not yet have local sources of the necessary raw stone material. The prevalence of mostly soft non-abrasive heat-resistant rocks for TGA throughout Eurasia indicates that this was not random and allows us to conclude that this was a purposeful choice of raw material.

\subsection{Massive fragmentation and nature of fractures}

More than half of the TGA (55\%) are broken, but demonstrate no signs of physical impact (a search for such marks yielded no results). The only exception is an intentionally 
broken TGA from the most recent burials at Borovyanka-17 and Ust-Isha. The broken items all have the ragged edges of fractures, despite the dominance of the extreme softness of the raw material, which can be easily processed by sawing and grinding, but not by percussion or direct impact (Aleksashenko 2004: 245-247). This may support the idea that fire was the cause of fracturing. This is also demonstrated by the context of certain TGA which were found in situ on a charcoal lens (Shabarakh Usu, Subsite 1, Mongolia, Fairservis 1993: 41; Roza Vetrov-2, West Siberia, Alexander Tkachev, personal communication).

Fire may also account for the "sooty" polish of grooves, as well as tiny inclusions of soot in the surface of some TGA, cracks, and what may be regarded as a baking crust (Aleksashenko 2004: 248-251). Final proof is provided by the results of X-ray diffraction analyses of some Near Eastern TGA, carried out at the Sackler Laboratory at Columbia University (Drew 1970). Changes in the mineral structure of the samples suggested strong heating. The original chlorite has been decomposed on the surface leaving iron oxide minerals within the tiny fractures. Some samples revealed a poorly crystallized structure of the mineral chlorite in which some olivine was presented, but olivine can be achieved from chlorite heated to $1000^{\circ} \mathrm{C}$ or by heating at much lower temperatures for longer periods of time. "All that can be said with certainty is that a fairly heat-resistant rock shows clear evidence of having had its surface subjected to a considerable amount of heat” (Drew 1970: 840).

\subsection{Shape and calibre (in-circle diameter) of the groove}

The softness of the rocks allows various shapes and sizes of TGA and their grooves. Item morphology, as well as the length, width, and height of TGA, vary greatly, but the diameter of the in-circle (Figure 5) of the grooves is always in the same range from 7 to $19 \mathrm{~mm}$, with the dominant rounded (semi-oval shape) profile of the cut, across all the territories and throughout all the times of TGA existence (Usacheva 2013a: 39-40, table 16, 18).

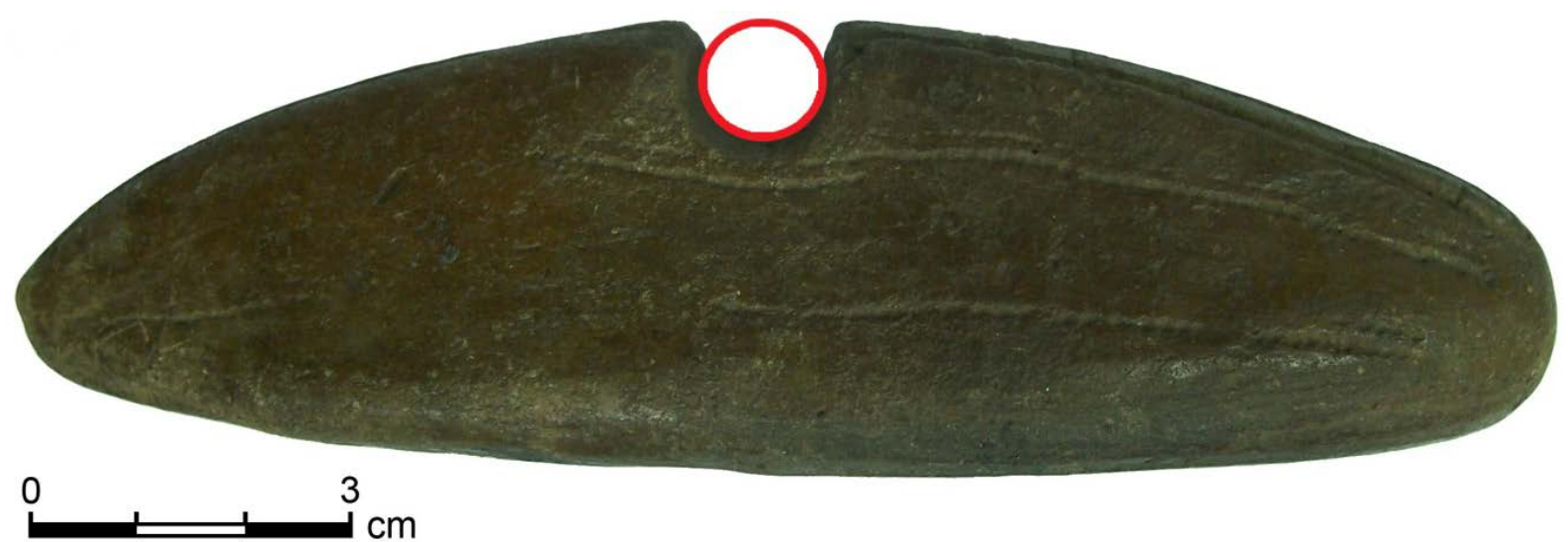

Figure 5. The diameter of the groove in-circle.

There are several exceptions related to unfinished items (in the Urals), where the groove is roughly defined but its formation is not complete, or it was not used often, and the traces of use have not smoothed the initial angulation of the cross-section (Table 2). Nonetheless, at least some of the items with triangular and rectangular cuts (Near East, basalt grooved stones) could have had their own independent function that set them apart from other TGA, for example as bead shapers, sharpeners, or for smoothing wooden or bone shafts and other objects (Solecki \& Solecki 1970: 839; Savage 2014: 179-185; Groman-Yaroslavski et al. 2015: 37). 
Table 2 The profile of the groove.

\begin{tabular}{|c|c|c|}
\hline Transverse Profile & $\mathbf{n}$ & $\%$ \\
\hline Semi-ovate & 292 & 84.4 \\
\hline Rectangular & 29 & 8.4 \\
\hline Triangular & 13 & 3.7 \\
\hline Pentagonal & 1 & 0.3 \\
\hline Unfinished & 11 & 3.2 \\
\hline Total & 346 & 100 \\
\hline
\end{tabular}

\subsection{Use-wear traces}

Traces of use can be seen by the naked eye in the grooves of many items. They can be explained by variations in the duration or frequency of their use. Use-wear macro-analyses ( $n=125,27.8 \%$ of the assemblage) and microscopic analyses (for the northern Eurasia assemblage, $n=70,15.6 \%$ and for the southern Levant, $n=$ at least two dozen) have been made on TGA by researchers from research centres in Moscow, St. Petersburg, Yekaterinburg, Nizhniy Tagil, Tyumen, Haifa, and Peterborough (Korobkova 1963; Korobkova \& Sharovskaya 1983; Aleksashenko 2004; Skochina 2013; Savage 2014, Groman-Yaroslavski et al. 2015). A variety of microscope, lighting, and imaging equipment was used in this study, with low $(5 x-50 x)$ and high $(50 x-500 x)$ magnification. The latest measurements of the northern Eurasia TGA assemblage were observed through the stereomicroscope MSP-1, documented with a Canon EOS1100 camera with magnification set to 20x, as well as the metallographic microscope Olympus BX-51 and documented with a ProgRres C10 camera with magnification set to 50x. To enhance the clarity of the images, the Helicon focus imaging software was used. The southern Levant grooved stones were studied using American Optics AO569, Zeiss, Nikon SMZ 745; 1000, Wild M4 stereomicroscopes, and metallographic microscopes such as Olympus BMHJ and Nikon Eclipse LV-150, and documented with Canon EOS T3i, Fuji F50fd, and Deltapix DP200 cameras (Savage 2014: 58).

Analysis revealed that the use-wear traces in the grooves of the northern Eurasia assemblage TGA are identical across the entire distribution range. Depending on the number of traces, they appear both quite densely and thus completely transform the initial micro-relief of the groove, or they may be limited to smoothing its higher areas. The most typical use-wear marks in the grooves are smoothing or polish, with a dark, "sooty" undertone, thin longitudinal lines, and isolated transverse incisions (Figure 6). Thin longitudinal lines and isolated transverse incisions in grooves suggest that these were used for processing thin round objects, such as arrow and dart shafts (Korobkova 1963: 217; Krizhevskaya 1968: 69; Savage 2014: 175), made of soft and elastic materials, but not of bone (Aleksashenko 2004: 248).

Based on these traces, the character of the movement in the treated objects was reconstructed as a back and forth movement (long linear marks), with elements of rotation (transverse scratches) (Korobkova 1963: 217; Aleksashenko 2004: 248-249).

Savage's (2014) trace evidence study was focused on a few types of grooved stones, specifically on those which are often considered to be straighteners for arrow-shafts from Natufian and Neolithic sites in the southern Levant (northern Israel). The sample included a subset of the full variety of grooved stone forms, specifically, those with hyperbolic, Ushaped, or semi-circular grooves made from non-abrasive (basalt) and abrasive (sandstone, scoria) rocks (Savage 2014). The sandstone and scoria grooved stones demonstrated a 
functional variability of the grooved stone class quite different from those of basalt (Savage 2014: 243).

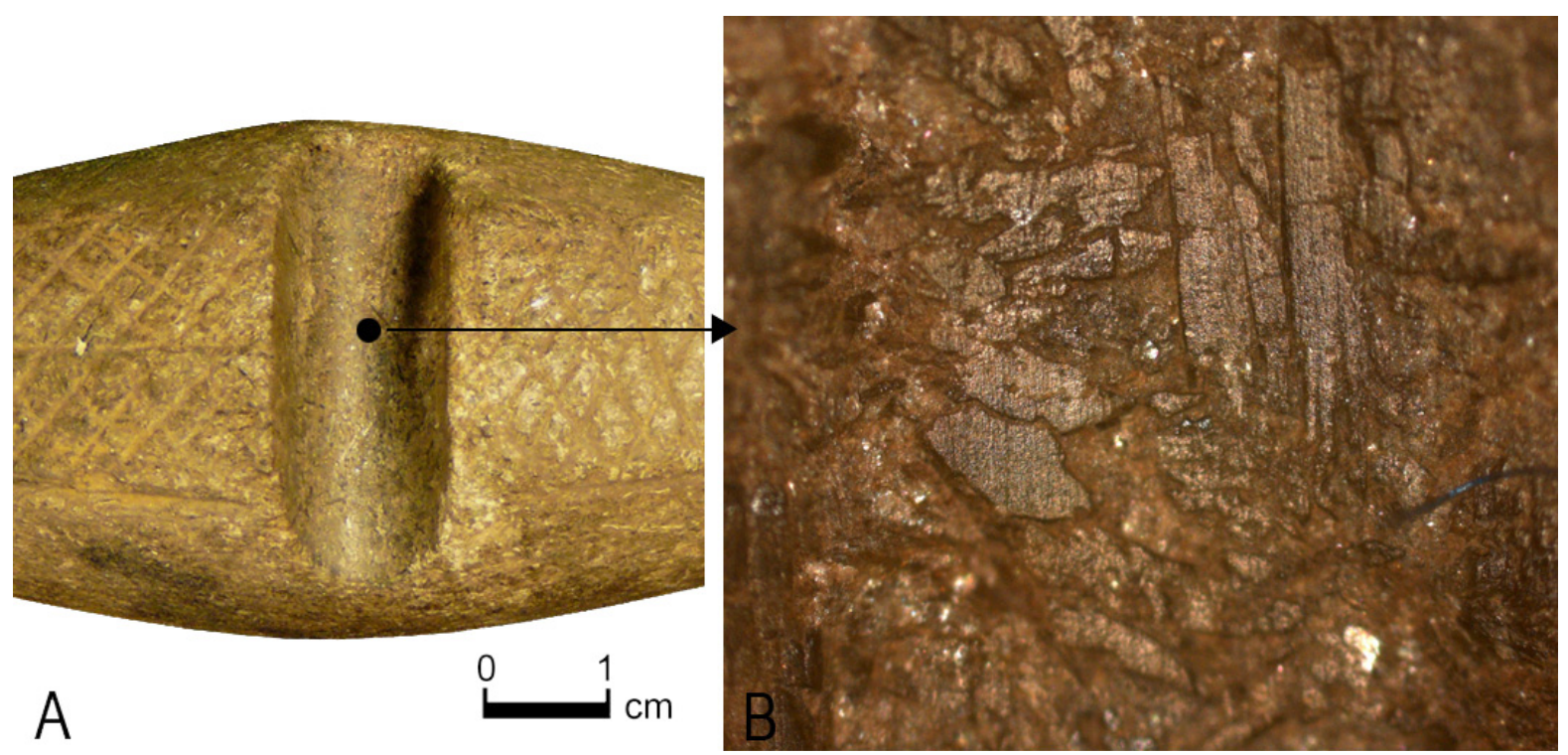

Figure 6. Kargopolie. A. Piece of the transverse grooved stone, B. microscopic use-wear traces in the groove (50x). (Photo by S.N. Skochina.)

The use-wear traces in the grooves of the basalt TGA exhibited on the grooved stones from the Natufian sites of Hayonim Terrace and Raqefet Cave are remarkably consistent, indicating that these tools represent a single functional type (Savage 2014: 182-183). The trace evidence descriptions of these samples are identical to those we can see in the grooves of the northern Eurasian assemblage of TGA. These wear patterns include: smoothed flat groove surfaces; signs of heating such as networks of small fissures; blackened patches; large pyroxene phenocrysts covered in a thick, smooth and sinuous micropolish; thin, rough or fluid micropolish covering most of the rest of the surface; and a suite of linear traces, such as scratches and striations, which are universally oriented to the longitudinal axis of the groove (Savage 2014: 241).

\subsection{Economic features of cultures that used TGA}

TGA first appeared and mostly existed in foraging societies and societies of farmers and cattle-breeders who still practiced fishing, hunting, and gathering on a large scale. Only four of the sixty cultures in which practices associated with TGA have been documented, are characterized by relatively advanced farming. In these cultures, TGA are either singular (Dzheitun, Shulaveri-Shomutepe cultures, Central Asia and Transcaucasia) or associated with a ritual context, as in the archaic assemblage of Klady, mound 31 (Maikop culture, Transcaucasia) and a sanctuary near Konstantinovskoye (Konstantinovskaya culture, Southern Russia; Usacheva 2006). The chronological cross-sections of TGA expansion show that as populations transitioned to agriculture or advanced cattle-breeding, TGA disappeared.

\subsection{Environmental contexts of sites}

Based on pedological and palynological data, palaeogeographic reconstructions demonstrated the similarity of the environmental contexts of sites with TGA such as the predominance of open landscapes (steppes, forest-steppes, semi-deserts; Dolukhanov 1989; Alexandrovskii 1997; Spiridonova \& Aleshinskaya 1999; Volkova et al. 2002; Tairov 2003). 
It seems obvious that the specific similar landscapes were the most optimal for the use of TGA. Finds outside such environments are very rare and do not extend beyond the contact zone with the above-described landscapes (Figure 4). TGAs are not found in forested zones. The same is true for the New World TGA. Observations of the environments of American tribes using TGA (ethnographic records and the American Museum of Natural History ethnographic collection) according to Solecki \& Solecki (1970: 836-837) and Usacheva (2013b: fig. 5) correspond to the observations regarding the environments of Eurasian sites with TGA.

\section{Discussion and functional reconstruction}

The presence of common characteristics for all of the artefacts in the areas under discussion suggests similarities between the TGA of northern Eurasia and those of the Near East. The features described above, especially the commonalities in the use-wear marks of the grooves, strongly support the idea of a single principal utilitarian function of TGA.

Thermal application was an important condition for realizing this function. This can be inferred from the heat-resistant properties of the raw materials, the type of fractures, the sooty undertone of the burnish in the grooves, the burn particles found in micro-relief, and the traces of strong heating in the TGA. Demand for such functions appeared to be directly tied to a specific economic level of society (here we are talking about the stages of foraging, early farming and early cattle-breeding societies) with representative types of landscapes (open, treeless, or poorly wooded country). In conjunction with existing data on the type of the treated objects, such as their prolonged form, soft and flexible material, and rounded crosssection, with a diameter of 7-19 mm, we believe that the TGA of northern Eurasia, as well as the transverse and longitudinal grooved stones of southwestern Asia were mainly related to the manufacture of shafts.

An experiment was designed to test if the shafts were made of wood or reed, and this technological process was practically reconstructed in order to test the TGA (Usacheva 2007: 146-155; Skochina 2013: 308-309; Usacheva \& Skochina 2015). Specific shapes of reeds (wet and dry) and wooden branches (willow) were tested. The observations from the grooves of experimental samples exhibited use-wear with remarkably similar morphology or wear patterns from all shapes of reeds and with pronounced differences from those of wood. Comparative analysis of use-wear signs in the grooves of experimental and archaeological samples (west Siberia) showed their full accordance with reed, but not with wood straightening (Figures 7 and 8). Evidence and use-wear traces outside the grooves are sporadic and vary across the regions. They could be associated with traces of a variety of additional functions.

Similar results were obtained by Savage (2014: 157-191) in the basalt Natufian grooved stones assemblage. The observations were interpreted through both experimental and ethnographic reference collections which consisted of grooved stones of known function and suggested that use-wear found on most of the Natufian grooved stones are best explained by contact with a resilient plant material. Reed straightening and bone burnishing (the unintended outcome of the bone abrasion experiments) were the only experimentally reproduced tasks which worked with any efficiency; however, bone produced use-wear is inconsistent with that found on the Natufian grooved stones and completely unknown in northern Eurasia patterns.

Our findings are in accordance to the conclusion of Savage (2014: 242) that only reed straightening, of all the tasks replicated experimentally, can explain such wear patterns, especially the evidence of heating and the apparent preference for a smooth, non-abrasive flat groove surface. 


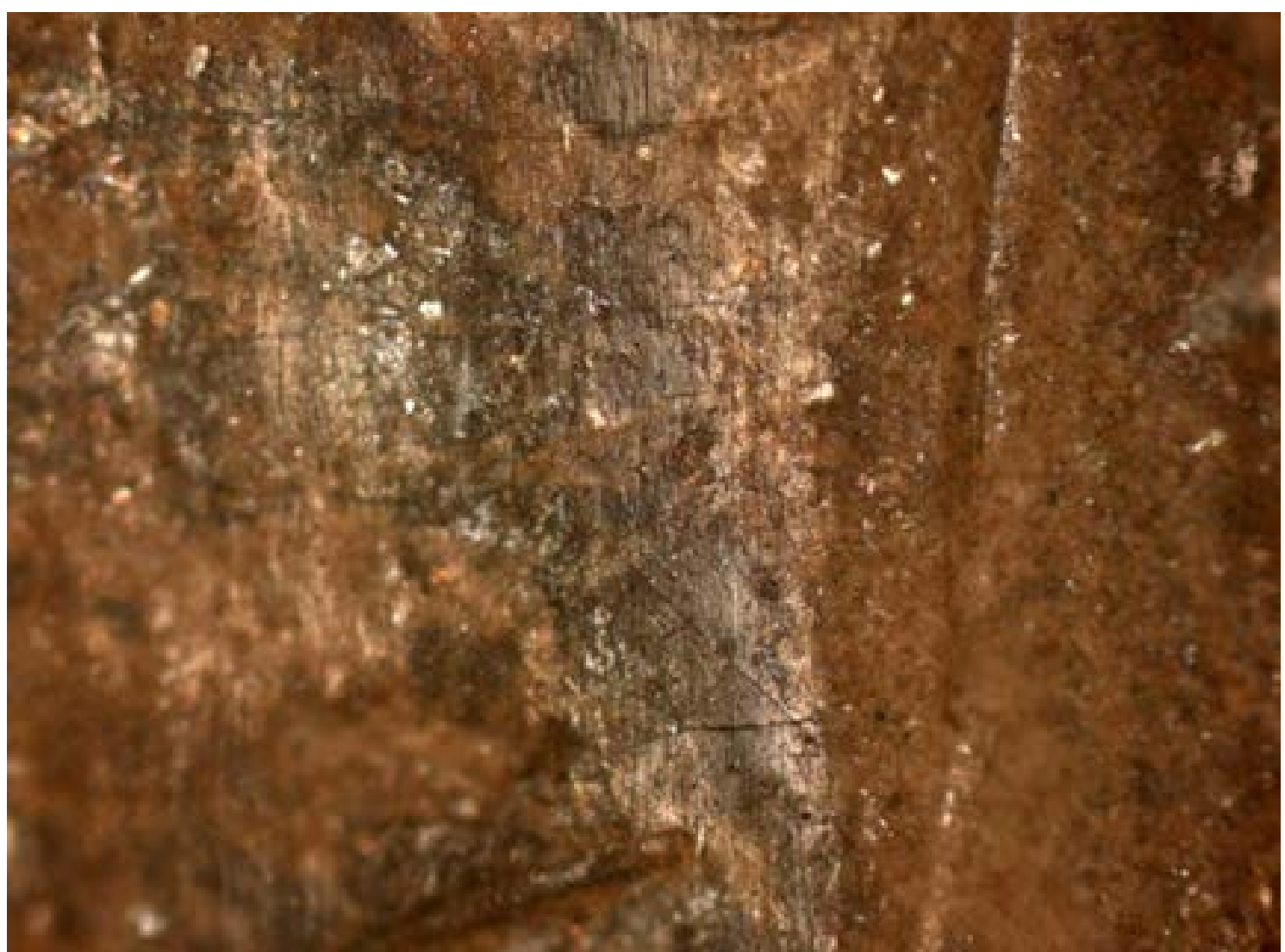

Figure 7. The use-wear traces (50x) in the groove left by straightening of the reed shafts. TGA talc replica. (Photo by S.N. Skochina.)

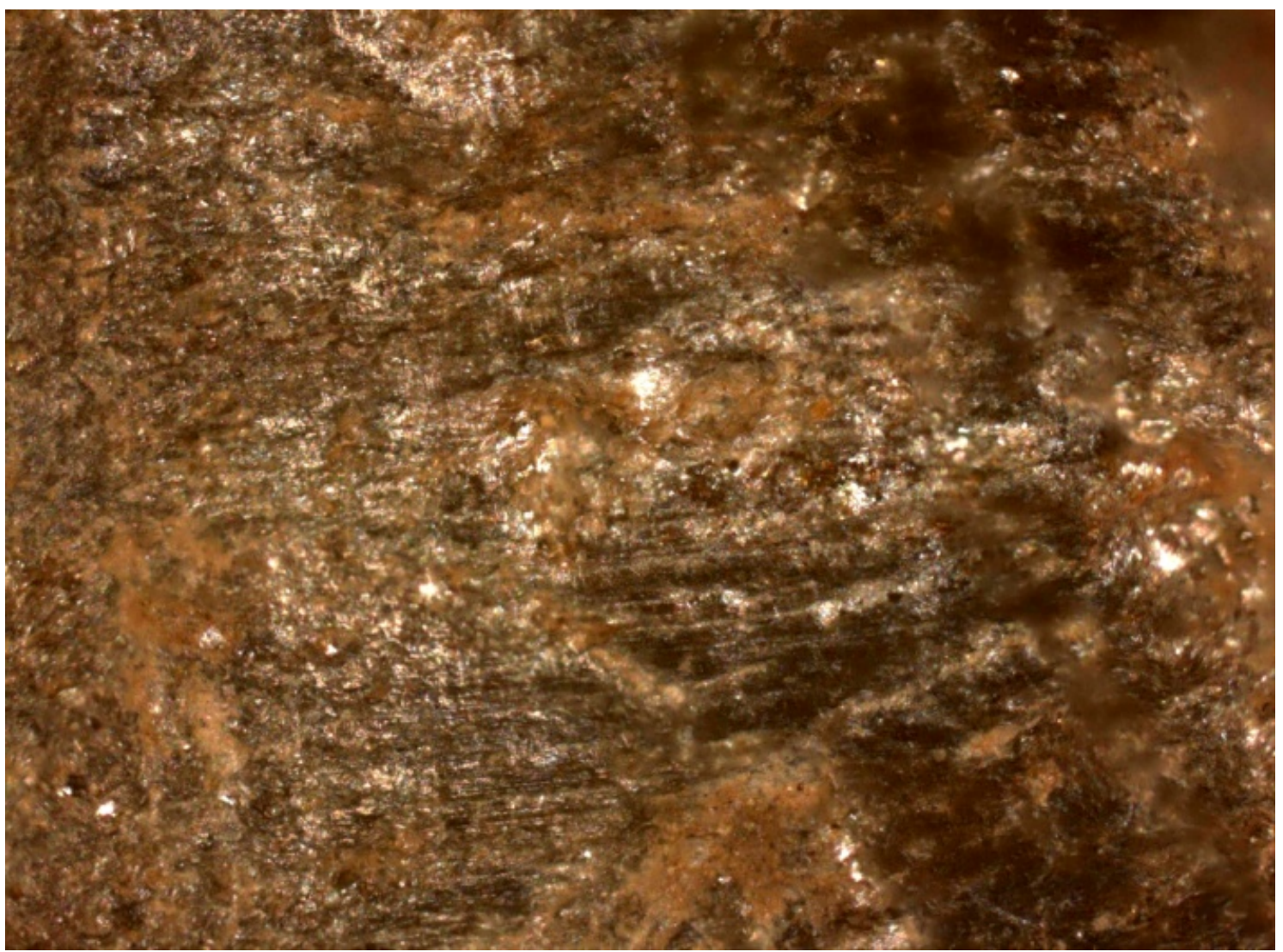

Figure 8. The use-wear traces (50x) in the groove left by straightening of the wooden (willow) shafts. TGA talc replica. (Photo by S.N. Skochina.) 
Both conclusions support the hypothesis of Solecki \& Solecki (1970: 838-839), suggesting that the different types of grooved stones are associated with a variety of functions, but those that were made of specially selected heat-resistant, nonabrasive (too soft) stone were mainly related to manufacture and were used for straightening cane and reed shafts under heating. The hypothesis was supported by the ethnographic data they collected, which detailed the process of reed shaft production by means of a heated tool with a transverse groove crafted from soft, heat-resistant rock, or clay when suitable stone was unavailable. Our empirically verified reconstruction of the process of reed shaft straightening, as well as the high rate of effectiveness in the use of grooved tools (Usacheva 2007: 146-155; Usacheva 2013: 105-111), gave results similar to those achieved by other researchers (Cosner 1951: 148; Wilke \& Quintero 2009: 128-129; Savage 2014: 68-100). Stone is heated in the fire, and the reed irregularities are placed into the groove. The curves in intermodal segments are passed to and fro with pressure along the groove of the hot stone until the generated steam softens the stem, and allows any bend to be straightened. The crooked nodes are fixed with a slight downward force with the elements of rotation. The groove acts as a local source of heat and as a fulcrum for straightening curves and other imperfections in the shaft. When the stem cools down, the reed remained straight.

This technique is quite different from that used for straightening wooden shafts. Twigs can be straightened by bending, most conveniently carried out using the hands, simple clamps, or perforated tools made of wood, bone, or stone. Such clamps can fix and control the bending point (Semenov 1968: 109; Usacheva 2013b: 60-61, fig. 3). Another technique widely employed in making wooden shafts in the Neolithic cultures of Eurasia involved abrasion. This required the use of special sandstone tools made of one or two semi-cylinders or bars with longitudinal grooves on the flat side (Gorodtsov 1915: 167; Müller-Karpe 1968: tables 134, 201 \& 400; Oshibkina 1996: figs. 88 \& 100). Another use of this action, apart from straightening, was abrading the exterior of wooden shafts (Semenov 1968: 109-110). As efficient as it is for wood, this technique is totally unsuitable for processing reeds. Sandstone and other abrasive materials damage the exterior of the reed, so the smoothest surface possible is desired. Soft non-abrasive rocks such as talc, chlorite, steatite, and fine-grained basalts are all suitable for the task.

The wooden shafts are more practical and easy to manufacture, which is why shafts were made from wood in forest areas. Open landscapes have a paucity of suitable wood. The existence of a straighteners' specialization depending on the type of raw materials (cane or wood) used for the shaft is supported by the geographic distribution of various types of tools. TGA are common in the Eurasian steppes and in similar open landscapes, where abrasive straighteners made of sandstone are not found. In the forest zone stretching from western Europe to eastern Siberia, sandstone straighteners are ubiquitous, whereas TGA are absent; in the forest-steppe zone, tools of both types occur.

Based on the findings above, we strongly support the idea that TGA from southwestern Asia and northern Eurasia are one and the same tool used for straightening cane and reed stems under heating.

\section{Conclusions}

TGA comprise a category of grooved items which include small $(3-23 \mathrm{~cm}$, most often 6$12 \mathrm{~cm}$ in length) soft, non-abrasive, heat-resistant, high calorific capacity stone or ceramic specimens varying in shape, quality, and decoration, with transverse grooves, $0.7-1.9 \mathrm{~cm}$ in diameter.

Some common features were found in TGA from southwestern Asia and northern Eurasia, such as heat-resistant raw materials, characteristics of fragmentation, lack of 
evidence for physical impact (supporting the idea that fire was the cause of fracturing), measurement of the in-circle diameter of the grooves, the environmental contexts of sites (the predominance of steppe, forest-steppe, and other landscapes), the similar economic level of the societies with which items are associated (foraging societies and those farmers and cattlebreeders who still practiced foraging on a large scale), use-wear marks, etc.

Based on these findings, we support the idea that these tools represent a single functional type. Our conclusion corresponds with the reconstruction of Solecki \& Solecki (1970) for "grooved stones." The high efficiency of TGA as straighteners of cane and reed shafts under heating explains the scale at which these artefacts spread through time and territory, indicating the circulation of reed shafts from the 15th to the early 2nd millennia, BCE. The discovery of a special tool mainly related to the manufacture of reed arrow shafts in Epipaleolithic times was significant and may be associated with a kind of technological innovation, with an effectiveness that is documented by the widest possible dissemination of TGA. After the transition to farming, the need for TGA gradually decreased and eventually disappeared.

The subject cannot be comprehensively discussed without mentioning that the straightening of reed stems was the basic, but not the only function of these tools, as supported by the use-wear marks found in some cases outside the groove and with their location on various parts of TGA surfaces. They are sporadic and, as a rule, specific to different areas, which does not allow us to interpret them in one and the same way. They could be associated with a variety of additional functions.

\section{Acknowledgments}

My cordial thanks go to all researchers - I.P. Alaeva, I.B. Vasil'ev, V.D. Viktorova, M.P. Vohmencev, R.S. Gabyashev, M.SH. Galimova, T.A. Gorbunova, S.A. Grigor'ev, M.G. Zhilin, V.F. Zajbert, V.A. Zakh, B.H. Kadikov, S.S. Kalieva, I.V. Kalinina, V.F. Kerner, YU.F. Kiryushin, V.T. Kovaleva, V.N. Logvin, V.K. Merc, V.I. Molodin, L.N. Myl'nikova, V.V. Nikitin, T.I. Nokhrina, L.I. Pogodin, YU.B. Serikov, D.YA. Telegin, A.A. Tkachev, I.V. Tolpeko, V.A. Hvostov, N.M. Chairkina, A.F. Shorin and particularly to my teacher V.T. Petrin - who allowed me to use their TGA in my study and to publish them. I would like to extend a very special thanks to N.A. Aleksashenko, Y.B. Serikov and S.N. Skochina for traceological analysis of TGA and Microphotograph; and B.V. Chesnokov for petrographic studies. I am deeply thankful to individuals associated with the American Museum of Natural History Department of Anthropology for granting me the opportunity to study and publish the museum exhibits under their care. It is a great pleasure to acknowledge the help and hospitality of friends and colleagues in different countries.

\section{References}

Aleksandrovskij, A.L. 1997, Степи Северного Кавказа в голоцене по данным палеопочвенных исследований. In: Степи и Кавказа, Культурные традиции. (Kozhin, P.M., Ed.), Труды государственного исторического музея Vol. 97. Государственный исторический музей, Moscow: p. 22-29. (in Russian) (“Steppes of the North Caucasus in the Holocene according to the Results of Paleosol Studies")

Aleksashenko, N.A. 2004, «Утюжки» под микроскопом. In: Культовые памятники горно-лесного Урала (Viktorova, V.D., Fedorova, N.V., Shirokova, V.N, Eds.), Институт истории и археологии Уральского отделения Российской академии наук, Ekaterinburg: p. 239-254. (in Russian) (“Utyuzhki under the microscope”) 
Algaze, G., Breuninger, R., Lightfoot, C., \& Rosenberg, M. 1991, The Tigris - Euphrates Archaeological Reconnaissance Project: A Preliminary Report of the 1989-1990 Seasons. Anatolica, 17: 175-240.

Bader, N.O. 1982, Некоторые результаты работ на раннеземледельческом поселении Кюльтепе в Северном Ираке. In: Археология Старого и Нового Света (Gulyaev, V.I., Ed.), Наука, Moscow: 50-57. (in Russian) ("Results of the Excavations at the Early Agricultural Site of Kültepe in Northern Iraq”)

Bader, O.N. \& Kalinina, I.V. 2003, Саузовская I стоянка. In: Труды Камской археологоэтнографической экспедиции Пермского государственного педагогического университета Vol. 3 (Belavin, A.M., Ed.), Пермский государственный педагогический университет, Perm: p. 11-30. (in Russian) ("Sauzovskaya I archaeological site")

Bobrov, V.V., Marochkin, A.G., \& Sokolov, P.G. 2006, Результаты работ на поселении Автодром-2 в 2006 году. In: Проблемы археологии, этнографии, антропологии Сибири и сопредельных территорий; Материаль Годовой сессии Института археологии и этнографии Сибирского отделения Российской академии наук, 2006 2 Vol. 12(1) (Derevyanko, A.P., Molodin, V.I., Eds.). Институт археологии и этнографии Сибирского отделения Российской академии наук, Novosibirsk: p. 269273. (in Russian) ("The results of the activities on the settlement Autodrome- 2 in 2006”)

Braidwood, L.S., Braidwood, R.J., Howe, B., Reed, C.A. \& Watson, P.J. (Eds.) 1983, Prehistoric Archaeology Along the Zagros Flanks, (1st ed.), Oriental Institute Publications Vol. 105. University of Chicago Press, Chicago, 542 p.

Bzhaniya, V.V. 1996, Кавказ. In: Археология. Неолит Северной Евразии (Oshibkina, S.V., Ed.), Наука, Moscow: p. 73-86. (in Russian) (“The Caucasus”)

Cosner, A.J. 1951, Arrowshaft-straightening with a grooved stone. American Antiquity, 17(2): 147-148. doi:10.2307/277254

Cybrij, V.V. 2004, Исследования ранненеолитической стоянки Раздорская 2 в 2003г. In: Историко-археологические исследования в г. Азове и на Нижнем Дону в 20032. Vol. 20 (Kiyashko, V.Y., Ed.), Азовский музей-заповедник, Azov: p. 34-40. (in Russian) (“The study of the Early Neolithic site Razdorskaya 2 in 2003”)

Dolukhanov, P.M. 1989, Природные условия эпохи мезолита на территории CССР. In: Археология СССР. Мезолит СССР (Kol'cov, L.V., Ed.), Наука, Moscow: p. 11-17. (in Russian) ("The natural conditions of Mesolithic age on the territory of the Union of Soviet Socialist Republics”)

Drew, I.M. 1970, Laboratory Report. In American Anthropologist, 72(4): 839-840 (in the article Solecki, R.L., \& Solecki, R.S. 1970, Grooved stones from Zawi Chemi Shanidar, a Protoneolithic site in Northern Iraq. American Anthropologist, 72(4): 831-841. doi:10.1525/aa.1970.72.4.02a00080

Fairservis, W. A. Jr. 1993, Archaeology of the Southern Gobi of Mongolia. Carolina Academic Press, Durham, 253 p.

Gornaya entsiklopediya [Горная энциклопедия - Mining Encyclopedia] 2015, Тальк, Горная энциклопедия. (in Russian) (“Talc. The mountain encyclopedia”). Accessed: 16 April 2016. URL: http://www.mining-enc.ru/t/talk/ 
Gorodtsov, V.A. 1915, Культуры бронзовой эпохи в Средней России. Отчёт Российского императорского исторического музея в Москве за 1914г, Moscow, 228 p. (in Russian) ("Bronze Age cultures in Middle Russia”)

Groman-Yaroslavski, I., Rosenberg, D., Kaufman, D., Yeshurun, R., \& Weinstein-Evron, M. 2015, The function of grooved basalt items from the Early Natufian layers of el-Wad Terrace, Israel: Perspective from use-wear analysis. In: Ground Stone Tools Artifacts and Society. An international Conference on Ground Stone Artifacts, Quarrying, Production, Function and Exchange. Program and abstract book, University of Haifa, Haifa: p. 37. URL: http://agsr2015.haifa.ac.il/images/pdf/JLS.pdf

Hvostov, V.A. 2001, Захоронения эпохи энеолита могильника Боровянка XVII в Среднем Прииртышье. In: Проблемы изучения неолита в Западной Сибири, (Zakh, V.A, Ed.), Institute of Problems of Northern Development, Siberian Branch, Russian Academy of Sciences, Tyumen: p. 134-139. (in Russian) ("Chalcolithic graves from the burial ground Borovyanka XVII at the Middle Irtysh River basin”)

Kiryushin, Yu.F., Kungurova, N.Yu., \& Kadikov, B.H. 2000, Древнейшие могильники северных предгорий Алтая, Алтайский университет, Barnaul, 117 p. (in Russian) (“Ancient burial grounds of the Northern foothills of the Altay mountains")

Klapchuk, M.N. 1970, Стоянка Караганда 15. Советская археология (Sovetskaya arheologiya), 4: 153-160. (in Russian) (“Karaganda 15 Site”)

Korobkova, G.F. 1963, Результаты изучения производственных функций каменных орудий из Усть-Нарыма. In: Новые методы в археологических исследованиях, (Rudenko, S.I., Ed.), Академия наук CCCP, Moscow, Leningrad: p. 215-233. (in Russian) ("The results of examining the production functions of stone tools from Ust'Narym”)

Korobkova, G.F., \& Sharovskaya, T.A. 1983, Функциональный анализ каменных и костяных изделий из курганов эпохи ранней бронзы у станиц Новослободной и Батуринской. In: Древние культуры евразийских степей (Masson, V.M., Ed.), Наука, Leningrad: p. 88-94. (in Russian) ("Functional analysis of stone and bone implements from barrows of Early Bronze Age near villages Novosvobodnaya and Baturinskaya”)

Kozlowski, S.K., \& Aurenche, O. 2005, Territories, boundaries and cultures in the Neolithic Near East. BAR International Series Vol. 1362, Archaeopress, Oxford, 275 p.

Krizhevskaya, L.Y. 1968, Неолит Южного Урала. Материалы и исследования по Археологии CCCP Vol. 141. Наука, Leningrad, 184 p. (in Russian) ("Neolithic of the Southern Urals")

Mellaart, J. 1982, Древнейшие цุивилизации Ближнего Востока, Наука. Главная редакция восточной литературы, Москва, 149 р. (in Russian) ("Earliest Civilizations of the Near East”).

Molodin, V.I. 1992, Древнее искусство Западной Сибири. Наука, Novosibirsk, 191 p. (in Russian) (“Ancient Art of Western Siberia”)

Müller-Karpe, H. 1968, Handbuch der Vorgeschichte. Jungsteinzeit, Vol. 2. Beck, Munich, 612 p. (in German) (Handbook of History. Neolithic) 
Nohrina, T.I., Usacheva, I.V., \& Gunchinsurehn, В. 1996, Новые данные о территории распространения «утюжков» и некоторые проблемы их изучения: Археологийн судлал (Arheologijn sudlal), 16(1-11): p. 76-81. (in Russian) ("New data on the spreading of "utyuzhki's" expansion and some problems of their study")

Oshibkina, S.V. (Ed.) 1996, Неолит Северной Евразии. Наука, Moscow, 377 p. (in Russian) ("The Neolithic of Northern Eurasia")

Rosenberg, D., Kaufman, D., Yeshurun, R., \& Weinstein-Evron, M. 2014, The broken record: the natufian groundstone assemblage from el-Wad terrace (Mount Carmel, Israel) attributes and their interpretation. Eurasian Prehistory, 9(1-2): 93-128.

Rudinskij, М.Y. 1956, Перший Вовнизький пізньонеолітичний могильник. In: Археологічні пам'ятки Української РСР (Danilenko, V.N., Ed.), Vol. 6. Академія наук Українськоі Радянськоі Соціалістичноі Республіки, Kiev: p. 151-161. (in Ukrainian) ("First Vovnigi the late Neolithic burial")

Savage, D.J. 2014, Arrows before agriculture? A functional study of Natufian and Neolithic grooved stones. Master of Arts thesis no. etd:299 at the Anthropology Department, Trent University, Peterborough (Canada), 327 p.

URL: http://digitalcollections.trentu.ca/islandora/object/etd\%3A299

Semenov, S.A. 1968, Развитие техники в каменном веке. Наука, Leningrad, 363 p. (in Russian) ("The development of technology in Stone Age")

Shekov, V.A., Myasnikova, O.V., \& Ivanov, A.A. 2010, Тальковый камень - его свойства и пути использования. In: Технологическая минералогия, методы переработки сырья и новые материалы (Shchipcov, V.V., Ed.), Карельский научный центр Российской академии наук, Petrozavodsk: p. 170-174. (in Russian) (“The Talc Stone its properties and ways of application”)

Skochina, S.N. 2013, Трасология эксперимента. In: «Утюжки» Евразии, Appendix 4. Наука, Novosibirsk: p. 308-309. (in Russian) (“Traceological Studying of Experiment”)

Solecki, R.L., \& Solecki, R.S. 1970, Grooved stones from Zawi Chemi Shanidar, a Protoneolithic site in Northern Iraq. American Anthropologist, 72(4): 831-841. doi:10.1525/aa.1970.72.4.02a00080

Spiridonova, E.A., \& Aleshinskaya, A.S. 1999, Периодизация неолита - энеолита Европейской России по данным палинологического анализа. Российская археология (Rossijskaya arheologiya), 1: 23-32. (in Russian) ("Periodization of the Neolithic - Chalcolithic of European Russia according to pollen analysis”)

Tairov, A.D. 2003, Изменения климата степей и лесостепей Центральной Евразии во II - I mыс. до н.э. Материалы к историческим реконструкциям. «Рифей», Chelyabinsk, 68 p. (in Russian) ("Climate changes at forest-steppe aria of Central Eurasia in the $2^{\text {nd }}$ to $1^{\text {st }}$ millennia BCE”)

Telegin, D.Ya. 1968, Дніпро-донецька культура. Nauka dumka, Kiev, 258 p. (in Ukraninan) ("The Dnieper-Donets Culture")

Usacheva, I.V. 2006, Утюжки» в культурах Евразии. Вестник археологии, антропологии и этнографии (Vestnik arkheologii, antropologii i etnografii), Tyumen, 6: 12-23. (in Russian) ("Utyuzhki" in the cultures of Eurasia)

URL: http://www.ipdn.ru/rics/va/_private/a6/12-23-usacheva.pdf 
Usacheva, I.V. 2007, “Утюжки» Евразии как исторический источник: Unpublished Ph.D. Institute of the problems of Northern development, Siberian Branch, Russian Academy of Sciences, Tyumen, 402 p. (in Russian) ("Utyuzhki” of Eurasia as the historical source).

Usacheva, I.V. 2012, Критический обзор гипотез функционального назначения «утюжков». Вестник археологии, антропологии и этнографии (Vestnik arkheologii, antropologii i etnografii), 16(1): 22-30. (in Russian) (Critical review of hypotheses the "utyuzhki’s functional purpose) URL: http://ipdn.ru/rics/va/_private/a16/22-30.pdf

Usacheva, I.V. 2013а, «Утюжки» Евразии. Наука, Novosibirsk, 352 p. (in Russian) (“Utyuzhki” of Eurasia)

Usacheva, I.V. 2013b, On the function of “grooved stones”. Archaeology, Ethnology and Anthropology of Eurasia, 41(4): 58-64. doi:10.1016/j.aeae.2014.07.007

Usacheva, I.V., \& Skochina, S. 2015, Experiments on production of reed arrow shafts by use of grooved stones: trace evidence. In: Ground Stone Artifacts and Society. An international Conference on Ground Stone Artifacts, Quarrying, Production, Function and Exchange. Program and abstract book, University of Haifa, Haifa: 65. URL: http://agsr2015.haifa.ac.il/images/pdf/JLS.pdf

Viktorova, V.D., \& Kerner, V.F. 1998, «Утюжки» с неолитических и энеолитических памятников Зауралья. Вопросы археологии Урала (Voprosy arheologii Urala), 23: 63-80. (in Russian) ("Utyuzhki” from the Neolithic and Chalcolithic sites of Eastern Urals”)

Vinogradov, A.V., \& Mamedov, E.D. 1975, Первобытный Лявлякан. Материалы Хорезмской экспедиции, Vol. 10, Наука, Moscow: 287 p. (in Russian) (“Prehistoric Lyavlyakan”)

Volkova, V.S., Gnibidenko, Z.N., \& Goryacheva, A.A. 2002, Климатическая ритмика голоцена центральной части Западно-Сибирской равнины (палинология, магнетизм). In: Основные закономерности глобальных и региональных изменений климата и природной среды в позднем кайнозое Сибири Vol. 1 (Vaganov, E.A., Derevyanko, A.P., Grachev, M.A., \& Zykin, V.S., Eds.), Институт археологии и этнографии Сибирского отделения Российской академии наук, Novosibirsk: p. 4857. (in Russian) ("Climatic rhythmic of the Holocene the Central part of the West Siberian plain (palynology, magnetism)”)

Vybornov, А. 2008, Неолит Волго-Камья. Самарский государственный педагогический университет, Samara, 490 p. (in Russian) (“The Neolithic Of Volga-Kama basin”)

Weinstein-Evron, M., Yeshurun, R., Kaufman, D., Boarretto, E., \& Eckmeier, E. 2012, New 14C dates for the Early Natufian of el-Wad Terrace, Mount Carmel, Israel. Radiocarbon, 54(3-4): 813-822. doi:10.2458/azu_js_rc.v54i3-4.16165

Wilke, P. J., \& Quintero, L. A. 2009, Getting it straight: shaft-straighteners in a grooved-stone world. In: Modesty and Patience: Studies and Memories in Honour of Nabil Qadi (Abu Salim) (H.J.K. Gebel, Z. Kafafi, \& Ghul. O., Eds.), Yarmouk University, Irbid, Jordan, Monographs of the Faculty of Archaeology and Anthropology Vol. 6. ex Oriente, Berlin: p. 127-134.

Yudin, A.I. 2004, Варфоломеевская стоянка и неолит степного Поволжья. Саратовский университет, Saratov, 200 p. (in Russian) ("Bartholomew site and the Neolithic age of the steppe Volga region”) 